\title{
(Wuthering Heights as a Gothic Novel)
}

\author{
Mushtaq Ahmed Kadhim Aldewan \\ (Department of Science, College of Basic Education / University of Sumer , Country :Iraq )
}

\begin{abstract}
Wuthering Heights "is an English genre of fiction popular in the 18th century. It is characterized by an atmosphere of mystery and horror and having a pseudo-medieval setting. It is a multi- generational Gothic and romantic novel. It revolves around the doomed love between Heathcliff and Catherine .Wuthering Heights sheds the lights with Lockwood, an owner of Heathcliff's, coming the home of his landlord Mr. Earnshaw, a Yorkshire Farmer and owner of Wuthering Heights, brings home an orphan from Liverpool. The baby is called Heathcliff and lives with the Earnshaw children, Hindley and Catherine.It is a movement that refers to ruin, decay, love, romance death, terror, and chaos, and unusual irrationality and compassion over rationality and sense.
\end{abstract}

\section{INTRODUCTION}

Wuthering Heights was written by a young woman named Emily Bronte who was one of the four children of hardworking clergyman, Patrick Bronte. Wuthering Heights, the romantic and passionate love story between the barbarous and uncomfortable Heathcliff and Catherine Earnshaw. The story is told through the narrator Mr Lockwood, a visitor to Wuthering Heights who is told the fascinating tale by Nelly Dean, the servant. Her tale revolves around the orphan Heathcliff, Catherine Earnshaw and her descendants, and the Linton relatives. Heathcliff was a enthusiastic gypsy child adopted by the Earnshaw family. He loves Catherine Earnshaw. She loves him, but she doesn't get married to him but she chooses for Edgar Linton, who has property and status. Heathcliff elopes with Isabella, Edgar's sister. Heathcliff becomes a rich and respected man. He could take over the Earnshaw family home and the Linton family home. Heathcliff loves Catherine throughout the story, in spite of he is led to inflict revenge as he cannot own her. He is buried next to her when he dies.

Bronte describes natural forces and events vividly while narrating the plot by means of Nelly Dean and Lockwood in order to display the connection between the inner and outer natural world in the Wuthering Heights.Virginia Woolf comments on Wuthering Heights, and considers that Brontë wants "to say something towards of her characters which are not only 'I love' or 'I hate,' but 'we, the whole human race' and 'you, the eternal powers." 76 Using the extreme and sometimes contemptible behavior of the difference among characters that Brontë is able to convey significant lessons about the world and universe as a whole, rather than just the lives of the characters themselves. Barbara Benedict explained Brontë herself in her role as a female author is an object of curiosity, yet she becomes even more of a curiosity in her brilliant ability to create a completely unique reality. Woolf describes Brontë as almost possessing magical powers .

The novel is filled with boorish, antagonistic characters that endlessly betray, mistreat and enact violence and revenge upon each other. The characters do not conform to any recognizable set of social values or follow any conventional moral code. However, despite the uncivilized characters and the ambiguous morality of the novel, Wuthering Heights was exceedingly popular in its time, and has continued to be regarded in high esteem over the years. While the novel is much loved and consistently praised for its beautiful poetic writing style, Wuthering Heights raises countless questions and lends itself to numerous interpretations. Within its unconventional framework, Wuthering Heights deals with timeless themes; obsessive love, the thirst for revenge, and the precariousness of social classes. Interwoven with ghostly appearances and references to demons and other supernatural elements, Wuthering Heights is an example of Gothic fiction, although in many ways Brontë breaks the mold of the genre. By snubbing convention in numerous ways, Wuthering Heights is a curious novel which has attracted curious readers for many generations.

\section{THE HORROR ELEMENT IN WUTHERING HEIGHTS}

Gothic narrative novel involves the concepts of paranoia, the barbaric, and the taboo.! Gothic fiction invariably involves a theme of persecution, often ambiguously rendered, with the victim of persecution being transformed into a persecutor, or vice versa.An undercurrent of insanity is a staple of any Gothic plot, with ambition or vengeance driving at least one character to the brink of madness.(Longmans ,1980,15). "Terror made me cruel ,Be with me always - take any form - drive me mad! only do not leave me in this abyss, where I cannot find you! Oh, God! it is unutterable! I can not live without my life! I can not live without my soul!" Emily Brontë, Wuthering Heights, 
The Gothic novel characteristically includes a story of the supernatural, the melodramatic or the macabre. It was a fashionable form of writing in the late eighteenth and early nineteenth centuries. Some of the characteristic features and conventions of the Gothic are listed in the box below often set in a sinister place such as a castle or ruined building, preferably with underground passages, labyrinths and dungeons. The supernatural element of the story might result from a curse or omen.David Daiches supports this point of view and expresses that "the homely and familiar and the wild and extravagant go together" in Emily Bronte's novel (Brontë,1985: 12). This emphasizes that while exploring the environment, Bronte also remarks the coexistence of passion to protest the dominance of nature over human psychology. "It is as if she could tear up all that we know human beings by, and fill these unrecognizable transparences with such a gust of life that they transcend reality. Hers, then, is the rarest of all power." Woolf, 102.

The supernatural may take the form of ghosts, nightmares or animation of previously inanimate objects. The hero is generally passion-driven, violent and melancholic when Catherine says in the following quotation. "I have not broken your heart - you have broken it; and in breaking it, you have broken mine".Arnold Kettle explains the deviation into vengefulness "Heathcliff becomes a monster: what he does to Isabella, to Hareton, to Cathy, to his son,even to wretched Hindley, is cruel and inhuman beyond normal thought. He seems to achieve new refinements of horror, new depths of degradation."(Kettle, .1958,67)

the gothic consistently approached the supernatural as if it can be described or observed in the mode of formal realism. By novelizing the supernatural, the monstrous and the unspeakable, the gothic attempts to inscribe the passions of fear and terror.(Ellis,2000,21-22)

\section{DEATH AND DESTRUCTION OF LIVES}

In 'Wuthering Heights' by Emily Bronte, the characters find destiny and death most of time, which causes $\mathrm{s}$ in a kind of intrigue with doom that colours the novel. In this lesson, we figure out at death in 'Wuthering Heights. 'Demise is all revolves around Wuthering Heights! Things start to descending for the residents of Wuthering Heights when Mr. and Mrs. Earnshaw die leaving siblings to take care oneself and themselves. In addition to mourning, the children have to learn about love in a loveless and harsh environment.

Bettina L. Knapp indicates since myths live outside temporal time, novel's universality and timelessness stem from characters' archetypal depths in this mysterious setting (Knapp, 1991: 107). This emphasizes that Wuthering Heights has become a myth through Emily Bronte's Puritanical cultural and literary canon. Moreover, the use of setting and nature imagery in Wuthering Heights helps to assess how human beings are affected by the environment and are in a struggle to oppose natural impact through their inner worlds. This implies that some characters, especially Heathcliff and Catherine, intend to suppress the strength of the natural landscape by their passion.

The novel is curious in its convoluted narrative-within-a-narrative format, its embodiment of the Gothic genre, and its lack of concern with social conventions, but it also contains curiosities in the form of supernatural phenomena, the portrayal of the female, and the character of Heathcliff. Curiosity in English culture, according to Barbara M. Benedict, can be defined as "the mark of a threatening ambition, an ambition that takes the form of a perceptible violation of species and categories: an ontological transgression that is registered empirically. (Cavaliero, 1995. 2.) There is no doubt that Earnshaw ,her father's death influenced Catherine. Not only she have to deal with mourning the loss of her father, but Catherine and Heathcliff are left in the care of her abusive brother, Hindley. In addition, Catherine's sister-in-law, Frances, dies in childbirth and Edgar's parents, Mr. and Mrs. Linton, die from an illness Catherine gave them as they were caring for her in their home.

Wuthering Heights itself is exploring by a curious inclination. Mr. Lockwood, a person entering the world of Wuthering Heights and Thrushcross Grange, is seeing after his first faced with Heathcliff and has a voracious urge to find out the history of the strange web of characters. Lockwood questions Nelly Dean, the longstanding housekeeper of Wuthering Heights, "hoping sincerely she would prove a regular gossip."(Brontë,1985,28) Indeed, Nelly Dean does prove to be a gossip. The curious Lockwood gets a perverse kind of thrill out of Nelly's stories, saying "I was excited, almost to a pitch of foolishness, through my nerves and my brain."Nelly also seems to gain a sense of pleasure out of gossip and begins her narrative, "waiting no further invitation to her story."'(Brontë,1985,30)

While Catherine is forward to her marriage offering to Edgar, Catherine tells Nelly,her housekeeper about a dream that she has had her death. "I was only going to say that heaven did not seem to be my home; and I broke my heart with weeping to come back to earth; and the angels were so angry that they flung me out into the middle of the heath on the top of Wuthering Heights; where I woke sobbing for joy." It looks odd and strange that Catherine would contemplate death what should be a happy and enjoyable time in her living, but her dream provides two goals. Firstly, it is a metaphor for how Catherine feels about leaving Wuthering Heights. Secondly, it threatens, warns of, Catherine's life after death. 
Catherine's Death chooses Edgar, it prompts Heathcliff to run away from Wuthering Heights. When he returns and begins courting Edgar's sister, Isabella, Edgar refuses to allow him back at Thrushcross Grange. As a result, Catherine stops eating and ends up going mad. When Heathcliff realizes the condition Catherine is in, he is angry with her for killing them both by betraying her heart and marrying Edgar. Heathcliff says, "Do I want to live? What kind of living will it be when you - oh, God! would you like to live with your soul in the grave?"For Heathcliff, living without Catherine is a fate worse than death. He actually feels like a part of him dies with her and begs her to haunt him rather than to leave him .Heathcliff has miserable stupidity of his character, child, and nothing else, which makes that dream enter your head. Pray, don't imagine that he conceals depths of benevolence and affection beneath a stern exterior! He's not a rough diamond - a pearl-containing oyster of a rustic: he's a fierce, pitiless, wolfish man. I never say to him, "Let this or that enemy alone, because it would be ungenerous or cruel to harm them;" I say, "Let them alone, because I should hate them to be wronged:" and he'd crush you like a sparrow's egg, Isabella, if he found you a troublesome charge. I know he couldn't love a Linton; [...] There's my picture: and I'm his friend"

The Death of Mr Earnshaw ,at of time Mr. Earnshaw began to fail. He had been active and healthy, yet his strength left him suddenly; and when he was confined to the chimney-corner he grew grievously irritable. A nothing vexed him; and suspected slights of his authority nearly threw him into fits. This was especially to be remarked if any one attempted to impose upon, or domineer over, his favourite: he was painfully jealous lest a word should be spoken amiss to him; seeming to have got into his head the notion that, because he liked Heathcliff, all hated, and longed to do him an ill-turn. This emphasizes that "they are said to be not merely human beings, with recognizably human needs, capabilities and failings, but the embodiment of the special 'forces,' 'energies,' or 'principles'." (Hagan, 1986: 67). They reflect their dangerous and revengeful side through their passion. To compare between Catherine and natural events in some cases, the winds on Wuthering Heights devastate the harmony of nature and Catherine destroys the cosmic unity through her marriage to Linton instead of Heathcliff. Actually, Catherine's conflicting emotions toward Heathcliff and Linton are reflected as a response to the destructive changing natural elements. Hagan expounds this frustration:

\section{THE ROMANTIC ELEMENT IN WUTHERING HEIGHTS}

"He's more myself than I am. Whatever our souls are made of, his and mine are the same".

First of all, we could fully understand the characteristics of romantic literature in 18th Century England through Wuthering Heights.Actually, the Romanticism believed that man, as an individual, is superior, so romantic novels really probe deeply inside characters. You can see this most obviously with Heathcliff and his rage and jealous, and also in Catherine, with her need to conform to social standards and her willful stubbornness. If all else perished and he remained, I could still continue to be; and if all else remained, and he were annihilated, the universe would turn to a mighty stranger. [. . .] My love for Linton is like the foliage in the woods. [. . . M My love for Heathcliff resembles the eternal rocks beneath: a source of little visible delight, but necessary. Nelly, I am Heathcliff. [. . .] not as a pleasure. [. . .] but as my own being. (Brontë,1985: 122)

Emily emphasizes the natural quality of her emotions by enriching her feelings for Heathcliff and Edgar by means of natural imagery. Moreover, Catherine indicates that she is the other self of Heathcliff, i.e., Heathcliff and Catherine's identities are intertwined. This is the reason why she enriches her feelings for Heathcliff."In the evening, the weather broke; the wind shifted from south to north-east and brought rain first and then sleet, and snow. On the morrow, one could hardly imagine that there had been three weeks of summer: the primroses and crocuses were hidden under wintry drifts; the larks were silent, the young leaves of the early trees smitten and blackened". (Brontë,1985,206) Similar to nature's beautiful descriptions in Wuthering Heights, Catherine is depicted as a beautiful person in a way responding to the beauty of nature. Landscape descriptions in Wuthering Heights become much clearer when

"I have just returned from a visit to my landlord in 1801 the solitary neighbour that I shall be troubled with. This is certainly a beautiful country! In all England, I do not believe that I could have fixed on a situation so completely removed from the stir of society. A perfect misanthropist's heaven: and Mr. Heathcliff and I are such a suitable pair to divide the desolation between us" ."It is as if she could tear up all that we know human beings by, and fill these unrecognizable transparences with such a gust of life that they transcend reality. Hers, then, is the rarest of all power." Woolf, 1964,102 .What vain weather-cocks we are! I, who had determined to hold myself independent of all social intercourse, and thanked my stars that, at length, I had lighted on a spot where it was next to impracticable, I, weak wretch, after maintaining till dusk a struggle with low spirits, and solitude, was finally compelled to strike my colours; and, under pretence of gaining information concerning the necessities of establishment". (Bronte, 1985: 74)

The fictional and romantic characters of Thrushcross Grange and Wuthering Heights are also in conflict with their environment in Wuthering Heights: "the gentle, moral Edgar Linton of the Grange contrasts with the malevolent and magnetic Heathcliff" (Gordon, 1989: 197). This controversial occasion signifies the existence of two different worlds signified through Wuthering Heights and Thrushcross Grange. 
While Wuthering Heights represents nature involving rivers, trees, rocks, leaves, air, and wind, Thrushcross Grange stands for the modern world of money, greed, and technology. Such a contrast ends up a rivalry in most cases and relatively signifies that characters overcome nature's dominance through dealing with the other problems in their lives and through being indifferent towards it. The existence of a dualistic structure in their lives implies the endless developing conflicts in these families. Unlike Wuthering Heights, Thrushcross Grange which is situated on a valley is elegant and comfortable and carries none of the grim features of the hills. It is "a splendid place carpeted with crimson, and crimson covered chairs and tables.

While stressing the relation between the beauty and that of nature, Catherine is depicted as part of the natural habitat she lives in. However, she becomes much more powerful than nature in respect to her passion. Catherine's consistency in her passion, ambition, and coolness is reflected by most critics and, thus, they support how Catherine contradicts with nature. Like most critics Phyllis Bentley, a very early critic who manifests the consistency in the outlook towards Bronte's masterpiece. Her powerful reason would have deduced new spheres of discovery from the knowledge of the old; and her strong imperious will would never have been daunted by opposition or difficulty; never have given way but with life." (Fraser 167) .The role of the younger Cathy, for example, becomes elevated to new prominence in this reading. If Heathcliff is the tyrannical monster enslaving the kingdom, it is Cathy who "slays the beast," so to speak. It is her love for Hareton that can be argued to have broken Heathcliff's spirit, and it is she who educates him and prepares him for his new role.

At the end of the novel, when Nelly narrates Lockwood about the death of Heathcliff and Catherine, she describes their fearlessness. they reflect their contradictory evaluations of each other (Sedgwick, 1986: 110) Being assessed as a non- human supernatural being, Heathcliff is noted as powerful and wild, --even more powerful than nature because of his passion to have dominance over it. Catherine Earnshaw, on the other hand, embodies the characteristics of both Heathcliff and Edgar. Besides, doubts begin to appear as to whether Heathcliff is human at all and people around him become the victim of his inhumanity10 (Sharma, 1994: 43). Heathcliff is depicted as wilder than nature in his natural peculiarities. Outlying hills have basically been portrayed as wild and fearful as well as mystic in its nature.

However, Heathcliff has been described as much wilder in his inner nature in Wuthering Heights: "His mouth watered to tear you with his teeth, because he is only half man - not so much and the - and the rest fiend!"11 (Bronte, 1985: 16).Catherine and Heathcliff's controversial love, thereby, becomes an immortal and universal love continuing on the moors which cannot be ended by death (Anderson, 1993: 114). This continuity reflects the power of their love. Heathcliff and Catherine's union is completed after death and becomes timeless as well as universal such as the natural forces of Wuthering Heights. This indicates that they respond to natural atmosphere by their eternal love to each other. However, their own passion which is more powerful than the hills also destroys their love. Heathcliff reflects how he is worried about losing Catherine

\section{CONCLUSION}

Emily's novel includes the relationship between Nature and humanity; and between Romance and horror; ways in which the soul might survive after death; personal betrayal and injustice; the imagination; separation and loss. Such themes must have been in her mind as she thought about the new novel. In Wuthering Heights she had learned the value of tight arranged in order of occurrence dominance ; it seems likely that this time she would want to start with a project, but this may be deceptive, since it is actually in the writing that Emily finds out her narrative novel. Emily Bronte achieved her artistic success through a combination of inspiration and hard work: this is not a startling conclusion. Gothic romances were mysteries, often involving the supernatural and heavily tinged with horror, and romance they were usually set against dark backgrounds of medieval ruins and haunted castles. Wuthering Heights, published in 1847, revolves around the passionate and destructive love between its two central characters, Edgar, and Heathcliff .Emily Bronte's headstrong and beautiful Catherine Earnshaw and her tall, dark, handsome, and brooding hero/devil, Heathcliff.

The Novel revolves around the family of the Earnshaws, owners of the called 'Wuthering Heights', where the defeniftly hedgehog, Heathcliff, is brought by the father of the foundling who has found him deserted in Liverpool, and who describes him 'as dark almost as if it came from the devil' for 'when Mr. Earnshaw first brings the kid home,Heathcliff and Hindley. Both boys, indeed, hate each other with a passion partly born of 'sibling rivalry', even though they are not blood relatives (at least such is not openly stated even if critics have inferred more than an act of mankind in Mr. Earnshaw's rescuing the boy and his wife's attendant hostility. When Earnshaw dies, Hindley wastes time in correcting the unlawful takeover of control from which he thinks he has got sorrow by recognizing Heathcliff to the level of a servant. Although, Cathy and Heathcliff have formed a pledged which nothing will ever cease, even Cathy's marriage to the wealthy Edgar Linton. 


\section{REFERENCES}

[1]. $\quad$ The Literature of Terror: A History of Gothic Fictions from 1765 to the Present Day (London. Longmans. 1980), Chapter 15\}.

[2]. $\quad$ \{Woolf, Virginia. "Jane Eyre and Wuthering Heights." Twentieth Century, 1964,102 \}

[3]. $\quad\{$ Kettle, Arnold. "Emily Brontë: Wuthering Heights." Twentieth Century, 1958,76$\}$.

[4]. Ellis, Markman. The History of Gothic Fiction. Edinburgh: Edinburgh University Press, 2000. 21-22. Print \}. 5-Cavaliero, Glen. The Supernatural and English Fiction. Oxford: Oxford University Press, 1995. 2. Print

[5]. $\quad\{$ Bronte, Emily, Wuthering Heights, 1985:,28\}

[6]. $\quad\{$ Bronte, Emily, Wuthering Heights, 1985:, 30\}

[7]. $\quad$ Hagan, J. (1986). Control of Sympathy in Wuthering Heights, The Brontes: A Collection of Critical Essays. (Ed: I. Gregor), Prentice Hall: 59-76-67, London $\}$

[8]. $\quad$ Bronte, Emily,Wuthering Heights, 1985: 122\}

[9]. $\quad$ Bronte, Emily, Wuthering Heights, 1985:,206\}

[10]. \{Woolf, Virginia. "Jane Eyre and Wuthering Heights." Twentieth Century, 1964,102-3-1\}

[11]. $\{$ Bronte, Emily,Wuthering Heights, 1985: 74\}

[12]. \{Gordon, F. (1989). A Preface to the Brontes, Longman, London.197\}

[13]. \{Fraser, Rebecca. The Brontë. New York: Fawcett Columbine, 1988.167\}

[14]. \{Sedgwick, E. K. (1986). The Coherence of Gothic Conventions, Arno, New York.110\}

[15]. \{Sharma, R. S. (1994). Wuthering Heights: A Commentary, Atlantic, New Delhi,43\}

[16]. \{Brontë, Emily, Wuthering Heights.1985: -16 \}

[17]. Anderson, W. E. (1993). The Lyrical Form of Wuthering Heights. Major Literary Characters: Heathcliff, (Ed: H. Bloom), Chelsea: 114-133, New York.

[18]. Www.iosrjournals.org 